of the movement from its beginnings in 1862. They do not give instances of the actual working of the scherne in any particular case, but its development as a whole is clearly indicated with tables of statistics and comments. As the Acts which control the working of the colleges are no fewer than nine, a certain amount of friction with the State authorities is inevitable. States differ in their resources and needs. But the authors agree that some Federal control of the research to be made is wise. An Act of 1935 arranged that Federal funds need not be "matched" by the State contributions- $-\mathbf{a}$ sensible provision. Agriculture is the main subject. Home economics appear to languish, from a table of time spent from 1928 until 1936. Experimental stations, as in agriculture, can scarcely bo arranged. But Morrill's initiative in 1862 has certainly proved fruitful for the farmer, if it has not provided the liberal education he contemplated. One difficulty to be faced is the duplication of work already being done by schools and colleges.

\section{Assistant for India at Kew}

Mr. C. F. C. Fischen, assistant for India at the Royal Botanic Gardens, Kew, is to retiro shortly. $\mathrm{He}$ joined the Herbarium in January 1925, while on furlough preparatory to retirement from the Indian Forest Service, which had been spent mainly in the Madras Presidency. In the samo year the death of Mr. J. S. Gamble left the "Flora of the Presidency of Madras" unfinished, and Fischer was charged with the completion of the work. This involved the working out of the soven families of Dicotyledons, the Conifere and the whole of the Monocotyledons. As assistant for India in the Herbarium he was also responsible for the identification of material from all parts of the Indian Empire, which during recent years has been mainly from Burma, the Himalayas including Southern Tibet, and the Madras Presidency. On Mr. Fischer's retirement in December, he will be succeeded by Mr. K. N. Kaul, who has already spent nearly six months at Kew. Mr. Kaul is a graduate of the University of Lucknow, where he has worked under Prof. B. Sahni.

\section{Announcements}

Prof. J. Gray, professor of zoology in the University of Cambridge, will deliver the Croonian Lecture of the Royal Society on November 16 at 2.30 p.m. The title of Prof. Gray's lecture is "Aspects of Animal I.ocomotion".

Dr. IVIllian W. Graves, professor and director of the Department of Neuro-psychiatry, St. Iouis School of Medicine, has received the Award of Merit of St. Louis Medical Society for his studies on inherited variations in relation to the problems of the human constitution.

AN institute for industrial medicine and particu. larly for the prevention and control of diseases due to dust will be opened shortly at Iglesias in Sardinia.
THe community education section of the American Dietetic Association has recently published a bibliography of normal nutrition. It can be obtained at the office of the Association, 185 North Wabash Avenue, Chicago, at 10 cents a copy.

Tre work of the Eugenies Society will be carried on at 69 Eccleston Square, London, S.W.1, during tho war, and an emergency committeo has been appointed, with full powers to act on behalf of the council. The quarterly publication of the Eugenics Review will be continued under the editorship of Dr. Maurice Nowfield.

Accordixg to a circular recently issued by the International Academy of the History of Sciences, the fifth International Congress of the History of Sciences will be held at Lausanne in September 1940, if the political and social situation of Europe permits. The permanent secretary of the Academy, M. Aldo Mielli, having now settled at Santa Fé in the Argentine Republic as director of the history of science in the University of Santa Fé, M. J. A. Vollgraff of Leyden has been appointed assistant secretary for Europe and the Mediterranean countries. The review Archeion, the official organ of the Academy, will henceforth be published at Santa Fé instead of at Rome as hitherto.

The Finney-Howell Research Foundation, Inc., announces fellowships for 1940 . This Foundation was provided for in the will of the late Dr. George Walker of Baltimore for tho support of "research work into the cause of causes and the treatment of cancer". Fellowships carrying an annual stipend of 2,000 dollars are awarded for the period of one year, with the possibility of renewal up to three years; when deemed wise by tho Board of Directors, special grants of limited sums may be made to support the work carried on under a fellowship. Applications for fellowships for 1940 should be made at the office of Foundation, 1211 Cathedral Street, Baltimore, Mary. land, by January 1, 1910.

Reference was mado in Nature of October 21, p. 714, to the British Association Research Committee on Blood Groups among Primitive Peoples; it should have been stated that the work referred to was done by, and under, Prof. R. Ruggles Gates.

Under the title "Prehistoric Indian Village, Now Mexico" reference was made in NATure of September 23 , p. 542 , to the work of an expedition under the leadership of Dr. Paul S. Martin. We are informed that Dr. Martin is, and has been for several years, chief curator of the Department of Anthropology of the Field Museum of Natural History, Chicago, and the oxpedition referred to is the ninth that Dr. Martin has undertaken for the Museum. The state. ment that the expedition was sent out by tho American MIuseum of Natural History of Now York is incorrect. 